\title{
Neighborhood location and its association with place attachment and residential satisfaction
}

\author{
Elif Aksel
}

Department of Interior Architecture and Environmental Design, Bilkent University, Ankara, Turkey and Department of Interior Architecture, Çankaya University, Ankara, Turkey, and

Çă̆rı İmamoğlu

Department of Interior Architecture and Environmental Design, Bilkent University, Ankara, Turkey

\begin{abstract}
Purpose - This paper aims to investigate the association of neighborhood location with place attachment and residential satisfaction.

Design/methodology/approach - First, the authors reviewed the literature on place attachment and residential satisfaction, and then generated a questionnaire based on the scales from the literature. The authors surveyed 135 respondents in two neighborhoods of Ankara, a metropolitan city in Turkey: one in the city center, the other in a suburb. To analyze the data, first, factor analysis, and later, multivariate analysis of variance and correlation tests were conducted.

Findings - The results indicated that place attachment and residential satisfaction were positively correlated, in congruence with the related literature; however, neighborhood location appeared to be associated only with residential satisfaction. The theoretical and practical implications of the results are discussed with respect to the recent issues on housing.

Originality/value - The effects of neighborhood location on place attachment and residential satisfaction (by comparing two different residential areas of the city) have not been adequately examined in earlier studies. The study results provide an understanding of the effectiveness of residential location on improving place attachment and residential satisfaction and contribute to the existing literature. Although the study findings may not be generalized to other locations in Turkey, this study contributed to the previous studies on place attachment and residential satisfaction by providing data from Turkish residents, which is less often examined.
\end{abstract}

Keywords Neighborhood, Place attachment, Residential satisfaction,

Built environment tectonics and technologies, Neighborhood location, Residential environment

Paper type Research paper

\section{Introduction}

There is much research on individuals' emotional connection to and residential satisfaction with their living environments (Altman and Low, 1992; Gifford, 2014; Lewicka, 2010, 2011). Place attachment has been examined at both the personal and community level (Anton and Lawrence, 2014; Brown and Raymond, 2007; Jorgersen and Stedman, 2001; Proshansky et al., 1983). Residential satisfaction, or the assessment of the perceived quality of a setting

An earlier version of this paper was presented in the 2017 AESOP Congress held in Lisbon, Portugal, during July 11-14, 2017.

Declaration of competing interest: The authors declare that they have no competing interests.

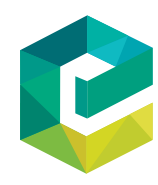


$\mathrm{OHI}$

45,3

(Stedman, 2002), is a significant indicator when evaluating the physical and social attributes of a residential environment in terms of how well it fulfills a person's needs. The present study aims to explore the role of neighborhood location on place attachment and residential satisfaction, specifically to investigate how living in or away from a city center may be associated with place attachment and residential satisfaction.

\subsection{Place attachment}

Altman and Low (1992) define place attachment as a symbolic bonding that gives a sense to places culturally and emotionally; this definition implies that one has symbolic and affective connections with an environment. It is interpreted as an emotional tie between people and places (Brown and Raymond, 2007; Hidalgo and Hernández, 2001). The dimensions of place attachment can be analyzed at two levels: social and physical attachment (Hidalgo and Hernández, 2001; Riger and Lavrakas, 1981). Social attachment includes social bonds, a sense of belonging and familiarity with other residents, while physical attachment may be affected by physical conditions, length of residence and homeownership (Riger and Lavrakas, 1981).

Place identity is related to social attachment. It indicates the cognitive and emotional significance of a place related to the experiences, emotions and interpersonal relations of people in that place (Williams and Vaske, 2003). It is an element of self-identity, which improves self-esteem and evokes one's sense of belonging to a community (Williams and Vaske, 2003). When people integrate their place-related thoughts, memories, values and experiences with their self-identity, they may better identify with their environment (Proshansky et al., 1983; Twigger-Ross and Uzzell, 1996). Breakwell's identity process theory states that there are four principles that influence identity: distinctiveness, continuity, self-efficacy and self-esteem. The places that promote these principles are more likely to positively influence identity structure (Breakwell, 1992; Speller, 2000).

Place dependence originates from the functional evaluation of a place in terms of how well it satisfies individuals' needs through allowing them to reach their goals (Shumaker and Taylor, 1983). It is related to the physical opportunities and characteristics of a place and indicates the conditions that are needed to fulfill and promote one's personal needs (Jorgersen and Stedman, 2001; Mandal, 2016).

Attachment to social environment is strongly associated with local bonding and the relations that individuals generate within their environments (Hay, 1998; Hidalgo and Hernández, 2001; Kyle and Chick, 2007; Raymond et al., 2010). Moreover, the scale of a place, such as homes, neighborhoods and cities, has been found to be influential on individuals' affective ties to places (Casakin et al., 2015; Hidalgo and Hernández, 2001; Lewicka, 2010). One's experiences in, and familiarity with, places can be effective in starting this emotional process (Roberts, 1996). Riger and Lavrakas (1981) claim that attachment comprises social bonds, the sense of belonging to the local environment as well as familiarity with that environment. The longer a person lives in a place, the higher the person's attachment to the place (Hammitt et al., 2006; Hummon, 1992; Raymond et al., 2010; Walker and Ryan, 2008). Being familiar with a place may allow individuals to feel safe, rooted and included in a community (Hammitt et al., 2006).

\subsection{Residential satisfaction}

There have been different approaches to the definition of "satisfaction" in terms of the relationships between people and places (Galster, 1987; Mesch and Manor, 1998; Stedman, 2002). The attitudes, meanings and knowledge related to the cognitive evaluation of an environment take a considerable role in the determination of place satisfaction (Stedman, 2002). Mesch and Manor (1998) define residential satisfaction as the assessment of the physical and 
social characteristics of a place. Factors affecting residential satisfaction can be analyzed in terms of their individual, social and environmental aspects (Ibem and Aduwo, 2013). Personal or family attributes such as age, gender, income level and family size are related to individual factors (Fornara et al., 2010; Hay, 1998; Zhang and Lu, 2016). The social atmosphere of a neighborhood, one's local involvement and one's social relations with neighbors as well as one's sense of community, privacy and safety are all important elements that provide social satisfaction for residents (Fornara et al., 2010; Sirgy and Cornwell, 2002; Zhang and Lu, 2016). Elements related to one's built environment also have an impact on residential satisfaction; green open spaces and recreational areas, as well as architectural style, building quality and size are significant components (Sirgy and Cornwell, 2002; Zhang and Lu, 2016).

Based on the above, the conceptual framework of the study displaying the relationships between the place of residence, place attachment and residential satisfaction is presented in Figure 1. This framework emphasizes the multidimensionality of both place attachment and residential satisfaction, together with the interaction between them by considering the place of residence. In the present study, we consider the place of residence as an independent variable in terms of understanding the differences in the level of place attachment and residential satisfaction and the relationships between them.

In light of this research, we first aimed to explore how neighborhood location may affect place attachment and residential satisfaction. Furthermore, we investigated the relationships between place attachment and residential satisfaction. There is research indicating different predictors of place attachment, which are social and physical factors such as age, length of residence, homeownership status, type of housing and neighborhood ties (Clark et al., 2017; Lewicka, 2010). Earlier studies also concentrated on residential satisfaction by indicating the effects of the socio-demographic profile, housing characteristics, built environment and behavioral approaches (Abdullah et al., 2020; Zhang and Zhang, 2017). However, there is a gap in the literature in terms of understanding the effects of neighborhoods in urban and suburban areas that differ in the urban development process. Our research could contribute to the literature on both environmental psychology and urban design by analyzing the neighborhoods that have different urban transformation because of locations in the context of place attachment and residential satisfaction. Thus, the hypotheses of our study are:

H1. Regarding physical and social factors such as the distance and proximity to city centers and access to social amenities (Lewicka, 2011; Scannell and Gifford, 2010), we hypothesized that residents living in city centers have a higher level of place attachment when compared to those living in areas away from city centers.

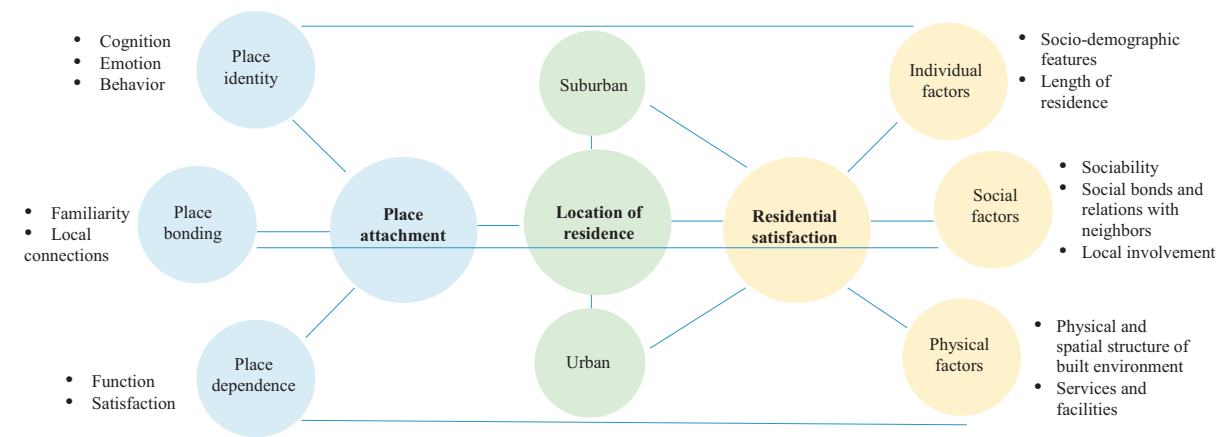
Neighborhood
location

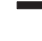


$\mathrm{OHI}$

45,3

\section{0}

H2. In line with the literature, we hypothesized that residents living in city centers have a higher level of residential satisfaction when compared to those living away from city centers (Bonaiuto et al., 1999; Fornara et al., 2010; Hidalgo and Hernández, 2001).

H3. In accordance with findings on the relationship between place attachment and residential satisfaction (Bonaiuto et al., 2003; Brown et al., 2003; Hur and MorrowJones, 2008; Jorgersen and Stedman, 2001; Mesch and Manor, 1998; Poortinga et al., 2017), we hypothesized that there is a positive correlation between place attachment and residential satisfaction.

\section{Method}

2.1 Sample

The respondents consisted of 75 women and 60 men from two neighborhoods in Çankaya, Ankara, Turkey; one neighborhood is located in the city center, and the other is $17 \mathrm{~km}$ away from it. We used non-random snowball sampling; this method was suitable to connect with respondents in the selected neighborhoods. Because of concerns regarding privacy, we did not ask the residents about their homeownership status, which may be a sensitive issue in Turkish culture. The age of the respondents ranged from 19-85 years $(M=46.50, S D=$ 14.96), with $2 \%$ having primary school education, $4 \%$ secondary school education, $19 \%$ a high-school diploma and the remaining 75\% graduate degrees. Of the residents, $74 \%$ stated that they spent most of their lives in metropolitan areas. Moreover, $66 \%$ of the residents stated that they have been living in their neighborhoods for at least 10-20 years, or more than 20 years. We observed that the respondents had sufficient length of stay in terms of representing their neighborhoods.

\subsection{The setting}

We conducted the research in Ayrancı and Çayyolu neighborhoods from the district of Çankaya, one of the oldest residential areas of Ankara, which reflects the privileged and the contemporary identity of the Turkish Republic historically (Erkip, 2010). Ayranc1 is located in the center of the city (Figure 2). The urbanization process of Ayranc1 started in the early

Figure 2.

Aerial view of Çayyolu and Ayrancı neighborhoods of Ankara

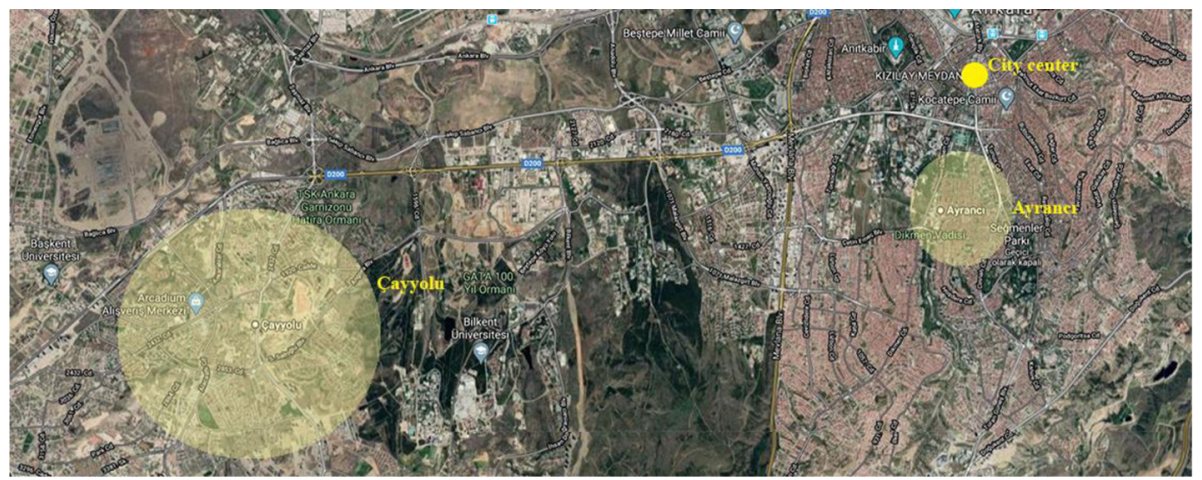

Source: www.google.com/maps 
1950s, with the urban transformation according to Jansen Master Plan after the establishment of the republic in 1923 (Aslanoğlu, 2001). When Ankara became the capital of Turkey, new residential areas were generated rapidly in many areas of the city to meet the housing needs (Aslanoğlu, 1986). Especially, as the city develops in the south direction, many vineyards, including Ayranc1, become residential areas. The spatial value of Ayranc1 has also increased because of its proximity to the Turkish parliament building and embassies, and this region has become a middle-upper-class neighborhood over time (Tuncer, 2014). Now, this neighborhood has five- or six-story traditional apartments with location similar design attributes in terms of physical, environmental and aesthetic quality (Seles and Afacan, 2019). Various social and physical facilities and services provide convenience for the residents living there.

Çayyolu is located in the southwestern part of Ankara and $17 \mathrm{~km}$ away from the city center (Figure 2). The residential development of Çayyolu started with the Çayyolu Mass Housing Plan by the Ankara 1990 Metropolitan Master Plan and the Metropolitan Municipality of Ankara (Erişen, 2003; Gültekin, 2015). Çayyolu neighborhood includes various residential units. The housing projects for the middle-upper class, which started in the late 1970s, increased, and in the late 1980s, with the support of the local government and public institutions (Gültekin, 2015). Some of these residential units are the production of the cooperative system adopted in the late 1990s (Ünver, 2019). They had significant effects in terms of defining Çayyolu as a neighborhood and providing new residential areas for the middle and upper-middle classes of Ankara. Currently, the existing housing typology of the neighborhood varies between high-rise buildings, gated communities and single-family houses. The developments in the real estate market, the appearance of prominent construction companies and the founding of large shopping malls in the 2000s affected the physical and social facilities of this region over time (Gültekin, 2015).

As we wanted to investigate the effect of neighborhood location, we conducted the research in those two neighborhoods with different urban transformations because of their historical developments explained above as well as their locations with respect to the city center. We selected these neighborhoods because both are under the jurisdiction of Çankaya Municipality, and their demographic profile is similar in terms of socio-economic status.

\subsection{Instrument and procedure}

We obtained data through a questionnaire consisting of two scales (Fornara et al., 2010; Lewicka, 2010): a place attachment scale and a perceived residential environment quality and neighborhood attachment scale. We developed the method of our study based on the previous research analyzing the residential quality and satisfaction by following quantitative methods (Bonaiuto et al., 2003, 2015; Ferreira et al., 2016). It would be efficient to use valid and reliable multi-item scales in terms of understanding the multidimensionality of place attachment and residential satisfaction (Fornara et al., 2010). The place attachment scale included 12 items related to positive (e.g. "I miss it when I am not here") and negative (e.g. "I leave this place with pleasure") statements about the place. We used this scale because it has satisfactory reliability and has been tested previously in several studies (Lewicka, 2005, 2007). The perceived residential environment quality and neighborhood attachment scale included 66 items related to the physical and social evaluation of the neighborhood in terms of the built environment (e.g. "It is pleasant to see this neighborhood"), connection and transportation (e.g. "The city center can be easily reached from this neighborhood"), parks and green areas (e.g. "There are green areas for relaxing in this neighborhood"), commercial services (e.g. "There are all kinds of stores in this neighborhood"), educational services (e.g. "This neighborhood has good school facilities"), 
$\mathrm{OHI}$

45,3

332

sociability (e.g. "Social services are adequate in this neighborhood"), security (e.g. "Here at night there is the risk of dangerous encounters"), environmental health (e.g. "This neighborhood is generally not polluted") and neighborhood attachment (e.g. "This neighborhood is part of me"). The data were collected through face-to-face surveys in the selected neighborhoods. We asked respondents to rate each item listed using a seven-point rating scale $(1=$ strongly disagree, $7=$ strongly agree). Participation was voluntary; respondents were informed that the data would only be used for research purposes and kept confidential. We also collected information involving participants' age, gender, level of education, socioeconomic status, length of residence and neighborhoods.

\section{Results}

First, a factor analysis was used to explore and identify the factor structures of place attachment and perceived residential environment quality. Next, we conducted a multivariate analysis of variance (MANOVA) to investigate the relationship of neighborhood location with place attachment and residential satisfaction. Lastly, we examined the correlations between place attachment and residential satisfaction.

\subsection{Factor analysis of place attachment scale}

We carried out a factor analysis with a varimax rotation for Lewicka's (2010) place attachment scale to identify the most influential dimensions. It yielded two factors explaining $52.03 \%$ of the variance (Table 1). We named the first factor "place identity." It emerged with an eigenvalue of 5.01 , which accounted for $41.72 \%$ of the variance. It included three items about the cognitive significance of a place associated with the place identity. The internal consistency of this factor was 0.82 . The second factor, named "place bonding," had an eigenvalue of 1.24 and accounted for $10.31 \%$ of the variance. It consisted of five items that measure the bonding of respondents by marking their positive and negative feelings about the place. The internal consistency of this factor was 0.81 .

\subsection{Factor analysis of perceived residential environment quality and neighborhood attachment scale}

For residential satisfaction, factor analysis revealed 14 factors in the initial stage. To reduce the number of components we conducted a second-order factor analysis, which yielded two factors and two variables, explaining a total of $58.85 \%$ of the variance. The first factor had an eigenvalue of 3.73 , which accounted for $26.67 \%$ of the variance. We named it "general evaluation of the neighborhood" (Table 2). The second factor emerged with an eigenvalue of 2.17, which accounted for $15.49 \%$. We named the second factor "recreational/care services

\begin{tabular}{lcc}
\hline Statements & $\begin{array}{c}\text { Factor 1 } \\
\text { Place identity }\end{array}$ & $\begin{array}{c}\text { Factor 2 } \\
\text { Place bonding }\end{array}$ \\
\hline I am proud of this place & 0.88 & \\
It is a part of me & 0.82 & \\
I feel secure here & 0.69 & 0.76 \\
I know this place very well & & -0.75 \\
I do not like this place & & 0.72 \\
I miss it when I am not here & & 0.70 \\
I defend it when somebody criticizes it & -0.58 \\
I leave this place with pleasure & &
\end{tabular}

Table 1.

Factors of place attachment and their loadings

I leave this place with pleasure 
and accessibility" (Table 2). The internal consistency of these factors was above 0.75 . There were two variables that were not supported by enough items; therefore, we could not interpret them as factors. The first of these two variables had an eigenvalue of 1.3 , which accounted for $9.52 \%$ of the variance. The two items loaded on this variable were "environmental health" and "aesthetics." The second variable had an eigenvalue of 1 , which accounted for $7.17 \%$ of the variance. An item loaded on this variable was "building volume."

\subsection{Investigating the difference in place attachment between locations}

We conducted a MANOVA for 2 (place attachment variables: place identity, place bonding) $\times 2$ (location: city, suburb) to explore the difference in the level of components of place attachment. We found no significant difference in terms of neighborhood location between the residents' level of place attachment $(F(2,132)=1.539, p>0.05)$. The residents living in the city center had a similar level of place identity $(M=5.78, S D=1.17)$ when compared with those living away from the city center $(M=5.42, S D=1.18)$. The level of place bonding of residents living in the city center $(M=5.81, S D=1.11)$ was also similar to those living away from the city center $(M=5.63, S D=1.15)$. According to the results above, we can state that $H 1$ does not support the evidence in the literature (Anton and Lawrence, 2014; Lewicka, 2011) but does make a contribution because we found no difference in the level of place attachment between the neighborhoods.

\subsection{Investigating the difference in residential satisfaction between neighborhoods}

We also carried out a MANOVA for 2 (residential satisfaction variables: general evaluation, recreational care/accessibility) $\times 2$ (location: city, suburb) to explore the difference between neighborhood locations in terms of residential satisfaction. The results showed a difference between the two neighborhoods in these dimensions $(F(2,132)=54.29, p<0.001)$. The level of satisfaction between residents living in the city center was different $(M=5.36, S D=0.87)$ compared to those living away from the city center $(M=4.81, S D=0.91)$. We can infer that the results for residential satisfaction supported $\mathrm{H} 2$ because we found a difference in the level of residential satisfaction between the neighborhoods.

\subsection{Correlations between place attachment and residential satisfaction components}

Spearman's rank-order correlation results indicate that there is an association between place attachment and residential satisfaction (Table 3). It shows that there is a correlation between the general evaluation of the neighborhood and place identity and place bonding

\begin{tabular}{lcrr}
\hline First-order factors & $\begin{array}{c}\text { Factor } 1 \\
\text { General evaluation }\end{array}$ & $\begin{array}{c}\text { Factor 2 } \\
\text { Recreational/care services and accessibility }\end{array}$ & \\
\cline { 1 - 2 } $\begin{array}{l}\text { External connection and } \\
\text { transportation }\end{array}$ & 0.72 & & \\
Educational services & 0.63 & & Table 2. \\
Neighborhood attachment & 0.63 & 0.69 & Second-order factors \\
Upkeep & 0.60 & 0.69 & of residential \\
Sociability & 0.60 & 0.67 & satisfaction and their \\
Parks and green areas & & 0.67 & loadings \\
Social care & & 0.57 & \\
Commercial services & & & \\
Social life and activities & & & \\
Parking and accessibility & &
\end{tabular}


$\mathrm{OHI}$

45,3

\section{4}

\section{Table 3.}

Correlations between place attachment (i.e. place identity, place bonding) and residential satisfaction (i.e. general evaluation, recreational care services/ accessibility) $(r(133)=0.54, p<0.01)$, and that there is a correlation between recreational/care services and accessibility and place bonding $(r(133)=0.22, p<0.01)$.

We can state that the results in Table 3 support $H 3$ because we found a correlation between the factors of place attachment and residential satisfaction (as we expected).

\section{Discussion}

The present study aims to contribute to the literature involving the relationship between place attachment and residential satisfaction by investigating the role of neighborhood location. Our results provided supportive evidence for our hypotheses, as further considered below.

\subsection{Comparison of place attachment and residential satisfaction in two residential areas}

The levels of place identity and place bonding of respondents living in the city center were similar to those living away from the city center. Anton and Lawrence (2014), who conducted a study with urban and rural residents, indicate that the place of residence is closely related to place attachment because rural residents have a higher level of place attachment than urban residents. Our results indicated no difference between urban and suburban respondents. Place identity is a part of personal and social identity because people are likely to define themselves by feeling attached to a certain place (Bernardo and PalmaOliveira, 2016). Feldman (1996) suggests that place attachment as a psychological construct connects the identity of a person to a place through ideas, feelings, values and behaviors; it becomes stronger through the daily experiences of a person in that place. We can infer that emotional ties, past experiences, memories and personal ideas may be influential in creating a social attachment to place. As stated in the literature, improving place identity is related to linking the cognitive elements of individuals (such as experiences, emotions, interpersonal interactions and memories) with self-identity (Proshansky et al., 1983; Scannell and Gifford, 2010; Twigger-Ross and Uzzell, 1996; Williams and Vaske, 2003). Meanings and emotional perception of experiences acquired in an environment that satisfies the psychological needs of individuals can strengthen place identity (Ujang, 2017). These psychological and social issues are as effective as physical and spatial characteristics in creating place identity. Thus, the place of residence (in terms of distance to the city center) may not be effective in shaping place identity because the location is a physical quality that may influence place dependence. We can also state other factors that may affect place identity and bonding; length of residence and homeownership. Former studies indicated that length of residence is a significant predictor of place identity (Clark et al., 2017; Ningning and Lijuan, 2017; Rollero and Piccoli, 2010). Of our respondents, $66 \%$ claimed that they have been living in their

\begin{tabular}{lcccc}
\hline Components of factor analysis & $\begin{array}{c}\text { Place } \\
\text { identity }\end{array}$ & $\begin{array}{c}\text { Place } \\
\text { bonding }\end{array}$ & $\begin{array}{c}\text { General } \\
\text { evaluation }\end{array}$ & $\begin{array}{c}\text { Recreational care } \\
\text { services/accessibility }\end{array}$ \\
\hline $\begin{array}{l}\text { Place identity } \\
\text { Place bonding }\end{array}$ & 1 & & & \\
$\begin{array}{l}\text { General evaluation } \\
\text { Recreational/care services and }\end{array}$ & 0.58 & 1 & & 1 \\
accessibility & $0.54^{*}$ & $0.54^{*}$ & 1 & \\
& 0.10 & $0.22^{*}$ & $0.24^{*}$ & \\
\hline
\end{tabular}


neighborhoods for at least ten years. Their length of stay could be sufficient in terms of improving place identity and bonding with their neighborhoods. Based on these factors, we can state that place identity or place bonding could be evaluated independently of the urbanization process or physical characteristics of a neighborhood.

We found a difference in the levels of residential satisfaction between the two neighborhoods we examined. The factors influencing residential satisfaction such as general evaluation of the neighborhoods and recreational care services/accessibility created this difference. The literature suggests that the physical and social attributes of neighborhoods are the primary predictors of one's satisfaction with their residential environment (Fornara et al., 2010; Sirgy and Cornwell, 2002). Yet, not only the physical and social features, but also individual factors such as age, income level, family size have an impact on neighborhood satisfaction (Bonaiuto et al., 2015; Bonaiuto et al., 2003; Dinç et al., 2014; Fornara et al., 2010; Huang et al., 2015; Hur and Morrow-Jones, 2008; Parkes et al., 2002; Sirgy and Cornwell, 2002; Zhang and Lu, 2016). Our findings support the literature: the level of satisfaction with certain services (such as external connection and transportation, educational services, upkeep and sociability) was higher for the respondents living in the city center than for those living away from the city center. Easy accessibility to these services in the city center may affect residential satisfaction. This result supports the findings of previous research, which found that having facilities located close to one's place of residence may improve residential satisfaction (Hamovitch and Peterson, 1969; Sirgy and Cornwell, 2002). Moreover, according to our results, the level of satisfaction with recreational facilities (such as parks and green areas) was higher for the respondents living away from the city center. These amenities may be more satisfactory in suburban areas compared to city centers; residents living in these neighborhoods may have positive experiences with these physical conditions.

\subsection{The relationship between place attachment and residential satisfaction}

We found a significant correlation between the factors of residential satisfaction and place bonding in accordance with former studies (Bonaiuto et al., 1999; Brown et al., 2003; Fornara et al., 2010; Hidalgo and Hernández, 2001; Hur and Morrow-Jones, 2008; Stedman, 2003). We can claim that being satisfied with the physical and social attributes of one's residential environment can improve how one bonds with places and as well as their sense of community. There was also a significant correlation between place identity and the general evaluation of the neighborhood in terms of external connection and transportation, educational services, upkeep and sociability. We can emphasize that the general physical and social conditions of a residential environment may direct the residents to create place identity as they identify themselves with their neighborhood.

\subsection{Limitations, strengths and suggestions for future studies}

One limitation of the present study was that we did not consider the housing type when determining its influence on place attachment and residential satisfaction. There may be a difference in the level of attachment and satisfaction between residents living in apartments and those living in detached houses or gated communities, which may be examined in future studies. Socioeconomic status and homeownership can also make a difference in the level of place attachment and residential satisfaction. However, the residences in the examined areas of the city were of similar socioeconomic status, so we did not see the need to inquire about this issue because of its sensitive nature (Erkip, 2010). We also did not ask the respondents about the location of their work or considerations regarding commute for work. Apart from these, the neighborhoods we selected were not very distant from each other. These issues could be investigated in future studies in terms of understanding their effects on the 
$\mathrm{OHI}$

45,3

perception of satisfaction and place attachment. Moreover, whether our results can be replicated with other neighborhoods such as those in the rural regions of Ankara could be studied.

Despite the limitations expressed above, we consider that our study has considerable strengths. First, the effects of neighborhood location on place attachment and residential satisfaction (by comparing two different residential areas of the city) have not been adequately examined in earlier studies. Our results provide an understanding of the effectiveness of residential location on improving place attachment and residential satisfaction and contribute to the existing literature. Although our findings may not be generalized to other locations in Turkey, this research contributed to the previous studies on place attachment and residential satisfaction by providing data from Turkish residents, which is less often examined. Our study may also have implications for future research on place attachment and residential satisfaction. The neoliberal structure in Turkey since the 1980 s created a decrease in welfare, polarization in social structure and an increase in cultural and social degeneration (Tanulku, 2012). As a result of this process, gated communities have emerged with the need of retirement from the urban life, enclosed personalized lifestyle, exclusiveness and security (Alkan-Gökler, 2017; Güzey, 2014; Tanulku, 2012). There are several studies analyzing place attachment in this context (Akçal, 2004; Bekleyen and Yilmaz-Ay, 2016; Edgü and Cimşit, 2011; Ergun and Kulkul, 2019; Kaba, 2018). The case settings we selected can provide a chance to see both traditional residential settings and gated communities in the urban and suburban context (Alkan-Gökler, 2017; Güzey, 2014; Özmen, 2020). A comparison study regarding gated communities in urban and suburban neighborhoods of Ankara or other metropolitans could provide different standpoints in terms of understanding how place attachment and residential satisfaction differentiate according to the housing and urbanization profile. Moreover, the analysis of these constructs in Turkey's mass housing projects (TOKI) that have become the prevalent type of housing could be another direction for further research. These projects are created by governmental urban transformation policies and offer low-cost and low-quality housing with their mass-produced architectural style and characteristics but have been criticized for their architectural quality (Gür and Dostoğlu, 2011; Iş1kkaya, 2016). Thus, it could be interesting to analyze the level of place attachment and residential satisfaction in these housing projects, especially in suburban neighborhoods of Ankara.

\section{Conclusion}

The factors that influence place attachment and residential satisfaction have been discussed with related results and further implications. We found that there is no difference in the level of place attachment relative to neighborhood location. We may infer that because place attachment is an affective-cognitive process, one's emotional ties, past experiences, memories and personal perspectives may be more influential in creating attachment to places than physical features such as location or distance to the city center; the physical attributes of a neighborhood may not significantly promote the emotional ties of residents to their residential environment.

On the other hand, we found a significant difference in the level of residential satisfaction between the two neighborhoods. We can claim that neighborhood location, i.e. being in the city center or away from the city center, can be an effective factor in satisfaction with one's residential environment. In our research, we analyzed and evaluated residential satisfaction as a measure of residential quality; the scale we used covered the physical and social characteristics of the neighborhood. Because residential satisfaction is a construct related to comfort and quality rather than emotional bonding, a place's physical attributes and quality 
have significant relevance in enhancing residents' satisfaction. Furthermore, we examined how place attachment is associated with residential satisfaction by correlating the factors related to place attachment with the factors related to residential satisfaction. Our results provide supportive evidence to the literature, and we can state that satisfaction with the physical and social opportunities with one's environment may be significant in influencing the affective bonds of individuals with their residential environment in terms of creating a sense of attachment.

In sum, our research points to the significance of neighborhood location by comparing the level of place attachment and residential satisfaction in different residential areas and provides further support that they are closely related but distinct constructs. Our findings may be beneficial for researchers as well as designers who want to investigate how physical, social and individual factors influence place attachment and residential satisfaction. The results of our study are expected to make a contribution to the literature as they provide a different perspective on this issue.

\section{References}

Abdullah, M.I., Abidin, N.Z., Basrah, N. and Alias, M.N. (2020), "Conceptual framework of residential satisfaction”, Environment-Behaviour Proceedings Journal, Vol. 5 No. 14, pp. 229-235.

Akçal, A. (2004), Place Attachment in Gated Communities: A Case Study in Bilkent Housing Settlements, Bilkent University.

Alkan-Gökler, L. (2017), "Gated communities in ankara: Are they a tool of social segregation?", International Journal of Housing Markets and Analysis, Vol. 10 No. 5, pp. 687-702.

Altman, I. and Low, S. (1992), Place Attachment, Vol. 12, Springer, New York, NY, doi: 10.1007/978-14684-8753-4_12.

Anton, C.E. and Lawrence, C. (2014), "Home is where the heart is: the effect of place of residence on place attachment and community participation", Journal of Environmental Psychology, Vol. 40, pp. 451-461.

Aslanoğlu, İ. (1986), "Evaluation of architectural developments in Turkey within the socio-economic and cultural framework of the 1923-38 period", METU Journal of the Faculty of Architecture, Vol. 7 No. 2, pp. 15-41.

Aslanoğlu, İ. (2001), Early Republican Era Architecture 1923-1938, METU Architecture Press, Ankara.

Bekleyen, A. and Yilmaz-Ay, I. (2016), “Are gated communities indispensable for residents?”, Urbani Izziv, Vol. 27 No. 1, pp. 149-161.

Bernardo, F. and Palma-Oliveira, J.M. (2016), "Urban neighbourhoods and intergroup relations: the importance of place identity", Journal of Environmental Psychology, Vol. 45, pp. 239-251.

Bonaiuto, M., Fornara, F. and Bonnes, M. (2003), "Indexes of perceived residential environment quality and neighbourhood attachment in urban environments: a confirmation study on the city of Rome", Landscape and Urban Planning, Vol. 65 Nos 1/2, pp. 41-52.

Bonaiuto, M., Aiello, A., Perucini, M., Bonnes, M. and Ercolani, A.P. (1999), "Multidimensional perception of residential environment", Journal of Environmental Psychology, Vol. 19 No. 4, doi: 10.1006/jevp.1999.0138.

Bonaiuto, M., Fornara, F., Ariccio, S., Cancellieri, G.U. and Rahimi, L. (2015), "Perceived residential environment quality indicators (PREQIs) relevance for UN-HABITAT city prosperity index (CPI)", Habitat International, Vol. 45, pp. 53-63.

Breakwell, G. (1992), "Processes of self-evaluation: efficacy and estrangement", Social Psychology of Identity and the Self, Surrey University Press, London, pp. 35-55. 
$\mathrm{OHI}$

45,3

Brown, G. and Raymond, C.M. (2007), "The relationship between place attachment and landscape values: toward mapping place attachment”, Applied Geography, Vol. 27 No. 2, pp. 89-111.

Brown, B., Perkins, D.D. and Brown, G. (2003), "Place attachment in a revitalizing neighborhood: individual and block levels of analysis", Journal of Environmental Psychology, Vol. 23 No. 3, pp. 259-271.

Casakin, H., Hernández, B. and Ruiz, C. (2015), "Place attachment and place identity in Israeli cities: the influence of city size", Cities, Vol. 42, pp. 224-230.

Clark, W.A.V., Duque-Calvache, R. and Palomares-Linares, I. (2017), "Place attachment and the decision to stay in the neighbourhood", Population, Space and Place, Vol. 23 No. 2, doi: 10.1002/psp.2001.

Dinç, P., Özbilen, E. and Bilir, M.B. (2014), "A multi-dimensional scale for measuring residential satisfaction (rs) in mass housing projects", Indoor and Built Environment, Vol. 23 No. 6, pp. 864-880.

Edgü, E. and Cimsiit, F. (2011), "Island living as a gated community: place attachment in an isolated environment", A/Z ITU Journal of the Faculty of Architecture, Vol. 8 No. 2, pp. 156-177.

Ergun, A. and Kulkul, C. (2019), "Defining semi-public space: case study in the gated communities of Yaşamkent”, Turkish Studies", , Vol. 20 No. 5, pp. 776-793.

Erişen, O. (2003), Suburbanization in Turkey within the Process of Integration to Global Development and a New Life-Style Settlement, METU.

Erkip, F. (2010), "Community and neighborhood relations in Ankara: an urban-suburban contrast", Cities, Vol. 27 No. 2, pp. 96-102.

Feldman, R.M. (1996), "Constancy and change in attachments to types of settlements”, Environment and Behavior, Vol. 28 No. 4, pp. 419-445.

Ferreira, I.A., Johansson, M., Sternudd, C. and Fornara, F. (2016), "Transport walking in urban neighbourhoods - impact of perceived neighbourhood qualities and emotional relationship", Landscape and Urban Planning, Vol. 150, pp. 60-69.

Fornara, F., Bonaiuto, M. and Bonnes, M. (2010), "Cross-validation of abbreviated perceived residential environment quality (PREQ) and neighborhood attachment (NA) indicators", Environment and Behavior, Vol. 42 No. 2, pp. 171-196.

Galster, G. (1987), "Identifying the correlates of dwelling satisfaction: an empirical critique", Environment and Behavior, Vol. 19 No. 5, pp. 539-568.

Gifford, R. (2014), "Environmental psychology matters", Annual Review of Psychology, Vol. 65 No. 1, pp. 541-579.

Gültekin, A.T. (2015), "Residents' awareness of urban and social living quality: the example of prof. Dr. Ahmet Taner Kışlalı neighborhood in Çayyolu/Ankara”, Journal of Ankara Studies, Vol. 3 No. 2 , pp. 165-182.

Gür, M. and Dostoğlu, N. (2011), "Affordable housing in Turkey: user satisfaction in TOKI houses", Open House International, Vol. 36 No. 3, pp. 49-58.

Güzey, Ö. (2014), "Neoliberal urbanism restructuring the city of Ankara: gated communities as a new life style in a suburban settlement", Cities, Vol. 36, pp. 93-106.

Hammitt, W.E., Backlund, E.A. and Bixler, R.D. (2006), "Place bonding for recreation places: conceptual and empirical development”, Leisure Studies, Vol. 25 No. 1, pp. 17-41.

Hamovitch, M. and Peterson, J. (1969), "Housing needs and satisfaction of the elderly", The Gerontologist, Vol. 9 No. 1, pp. 30-32.

Hay, R. (1998), "Sense of place in developmental context”, Journal of Environmental Psychology, Vol. 18 No. 1, pp. 5-29.

Hidalgo, M.C. and Hernández, B. (2001), "Place attachment: conceptual and empirical questions", Journal of Environmental Psychology, Vol. 21 No. 3, pp. 273-281. 
Huang, Z., Du, X. and Yu, X. (2015), "Home ownership and residential satisfaction: evidence from Hangzhou, China”, Habitat International, Vol. 49, pp. 74-83.

Hummon, D.M. (1992), “Community attachment”, Place Attachment, Springer, pp. 253-278.

Neighborhood location

Hur, M. and Morrow-Jones, H. (2008), "Factors that influence residents' satisfaction with neighborhoods", Environment and Behavior, Vol. 40 No. 5, pp. 619-635.

Ibem, E.O. and Aduwo, E.B. (2013), "Assessment of residential satisfaction in public housing in Ogun state, Nigeria”, Habitat International, Vol. 40, pp. 163-175.

Işıkkaya, A.D. (2016), "Housing policies in Turkey: Evolution of TOKI (governmental mass housing administration) as an urban design tool", Journal of Civil Engineering and Architecture, Vol. 10 No. 3, pp. 316-326.

Jorgersen, B.S. and Stedman, R.C. (2001), "Sense of place as an attitude: lakeshore owners attitudes toward their properties", Journal of Environmental Psychology, Vol. 21 No. 3, pp. 233-248.

Kaba, B. (2018), "Measuring neighborhood attachment and urban-related identity among residents of gated communities: a case study in Mavişehir", European Journal of Geography, Vol. 9 No. 2, pp. 66-80.

Kyle, G. and Chick, G. (2007), "The social construction of a sense of place", Leisure Sciences, Vol. 29 No. 3, pp. 209-225.

Lewicka, M. (2005), "Ways to make people active: the role of place attachment, cultural capital, and neighborhood ties", Journal of Environmental Psychology, Vol. 25 No. 4, pp. 381-395.

Lewicka, M. (2007), "Regional differentiation of identity: a comparison of Poland and Ukraine", Regional and Local Studies, No. 8, pp. 21-51.

Lewicka, M. (2010), "What makes neighborhood different from home and city? Effects of place scale on place attachment", Journal of Environmental Psychology, Vol. 30 No. 1, pp. 35-51.

Lewicka, M. (2011), "Place attachment: how far have we come in the last 40 years?", Journal of Environmental Psychology, Vol. 31 No. 3, pp. 207-230.

Mandal, A. (2016), "Size and type of places, geographical region, satisfaction with life, age, sex and place attachment", Polish Psychological Bulletin, Vol. 47 No. 1, pp. 159-169.

Mesch, G.S. and Manor, O. (1998), "Social ties, environmental perception, and local attachment", Environment and Behavior, Vol. 30 No. 4, pp. 504-519.

Ningning, F. and Lijuan, C. (2017), "The relation between restorative experience and place attachment: the role of environment preference and length of residence", Journal of Psychological Science, Vol. 5 No. 29.

Özmen, E.E. (2020), The Perception and Experience of Spatial Segregation: Dikmen 5th Stage Gecekondu Neighborhood and Park Oran Gated Community, METU.

Parkes, A., Kearns, A. and Atkinson, R. (2002), "What makes people dissatisfied with their neighbourhoods?”, Urban Studies, Vol. 39 No. 13, pp. 2413-2438.

Poortinga, W., Calve, T., Jones, N., Lannon, S., Rees, T., Rodgers, S.E., Lyons, R.A. and Johnson, R. (2017), "Neighborhood quality and attachment: validation of the revised residential environment assessment tool”, Environment and Behavior, Vol. 49 No. 3, pp. 255-282.

Proshansky, H.M., Fabian, A.K. and Kaminoff, R. (1983), "Place-identity: physical world socialization of the self", Journal of Environmental Psychology, Vol. 3 No. 1, pp. 57-83.

Raymond, C.M., Brown, G. and Weber, D. (2010), "The measurement of place attachment: personal, community, and environmental connections", Journal of Environmental Psychology, Vol. 30 No. 4, pp. 422-434.

Riger, S. and Lavrakas, P.J. (1981), "Community ties: patterns of attachment and social interaction in urban neighborhoods", American Journal of Community Psychology, Vol. 9 No. 1, pp. 55-66.

Roberts, E. (1996), "Place and spirit in public land management", in Driver, B.L. (Ed.), Nature and the Human Spirit: Toward an Expanded Land Management Ethic, Venture Publication, pp. 61-78. 
$\mathrm{OHI}$

45,3

Rollero, C. and Piccoli, N.D. (2010), "Place attachment, identification and environment perception: an empirical study", Journal of Environmental Psychology, Vol. 30 No. 2, pp. 198-205.

Scannell, L. and Gifford, R. (2010), "Defining place attachment: a tripartite organizing framework", Journal of Environmental Psychology, Vol. 30 No. 1, pp. 1-10.

Seles, E. and Afacan, Y. (2019), "Exploring the relationship between health and walkability", Open House International, Vol. 44 No. 1, pp. 44-52.

Shumaker, S.A. and Taylor, R.B. (1983), "Toward a clarification of people-place relationships: a model of attachment to place", in Feimer, N.R. and Geller, E.S. (Eds), Environmental Psychology: Directions and Perspectives, Vol. 2, pp. 19-25.

Sirgy, M.J. and Cornwell, T. (2002), "How neighbourhood features affect quality of life", Social Indicators Research, Vol. 59 No. 1, pp. 79-114.

Speller, G. (2000), A Community in Transition: A Longitudinal Study of Place Attachment and Identity Processes in the Context of an Enforced Relocation, University of Surrey.

Stedman, R.C. (2002), "Toward a social psychology of place: predicting behavior from place-based cognitions, attitude, and identity", Environment and Behavior, Vol. 34 No. 5, pp. 561-581.

Stedman, R.C. (2003), "Is it really just a social construction? The contribution of the physical environment to sense of place", Society and Natural Resources, Vol. 16 No. 8, pp. 671-685.

Tanulku, B. (2012), "Gated communities: from self-sufficient towns to active urban agents", Geoforum, Vol. 43 No. 3, pp. 518-528.

Tuncer, S. (2014), "Küçükesat: from vineyard houses to neighborhood”, İdealkent, Vol. 11, pp. 202-225.

Twigger-Ross, C. and Uzzell, D. (1996), "Place and identity processes", Journal of Environmental Psychology, Vol. 16 No. 3, pp. 205-220.

Ujang, N. (2017), "Place attachment and continuity of urban place identity", Asian Journal of Environment-Behaviour Studies, Vol. 2 No. 2, pp. 117-132.

Ünver, E. (2019), Investigation of the Neighborhood Unit in the Western Fringe of Ankara, METU.

Walker, A.J. and Ryan, R.L. (2008), "Place attachment and landscape preservation in rural new England: a Maine case study", Landscape and Urban Planning, Vol. 86 No. 2, pp. 141-152.

Williams, D.R. and Vaske, J. (2003), "The measurement of place attachment: validity and generalizability of a psychometric approach", Forest Science, Vol. 49 No. 6, pp. 830-840.

Zhang, C. and Lu, B. (2016), "Residential satisfaction in traditional and redeveloped inner city neighborhood: a tale of two neighborhoods in Beijing", Travel Behaviour and Society, Vol. 5, pp. 23-36.

Zhang, Z. and Zhang, J. (2017), "Perceived residential environment of neighborhood and subjective wellbeing among the elderly in China: a mediating role of sense of community", Journal of Environmental Psychology, Vol. 51, pp. 82-94.

\section{Corresponding author}

Elif Aksel can be contacted at: aksel@cankaya.edu.tr

For instructions on how to order reprints of this article, please visit our website:

www.emeraldgrouppublishing.com/licensing/reprints.htm

Or contact us for further details: permissions@emeraldinsight.com 